\title{
GERAKAN SOSIAL PEREMPUAN EKOFEMINISME DI PEGUNUNGAN KENDENG PROVINSI JAWA TENGAH MELAWAN PEMBANGUNAN TAMBANG SEMEN
}

\author{
Annisa Innal Fitri \\ Idil Akbar \\ Departemen Ilmu Pemerintahan \\ Fakultas Ilmu Sosial dan Ilmu Politik Universitas Padjadjaran \\ email: annisainnalfitri@gmail.com
}

\begin{abstract}
ABSTRAK
Tulisan ini bertujuan untuk melihat suatu gerakan sosial perempuan yang dapat berperan strategis untuk menguatkan gerakan-gerakan perlawanan masyarakat, sebagai agen untuk memperjuangkan hak-hak demokratis, keadilan dan pembebasan rakyat. Demikian pula halnya dalam gerakan tani, gerakan perempuan adalah sebagai salah satu elemen penggerak perjuangan rakyat (petani dan buruh tani) dalam memperjuangkan hak-hak mereka. Gerakan perempuan yang dibahas dalam tulisan kali ini adalah mengenai perlawanan para srikandi yang tinggal di sekitar Pegunungan Kendeng, yang setiap harinya melakukan aktivitas interaksi dengan alam. Saat ini Pegunungan Kendeng didirikan Pabrik Semen oleh PT Semen Indonesia, produsen semen raksasa yang merupakan Badan Usaha Milik Negara (BUMN), yang rencananya akan mulai beroperasi pada tahun 2017. Para remaja perempuan dan ibu disana menolak langkah apapun terkait pendirian pabrik semen karena diyakini akan merusak sumber daya air dan mematikan sektor pertanian. Tulisan ini disertai landasan literatur mengenai masyarakat sipil dan gerakan sosial.
\end{abstract}

Kata Kunci: masyarakat sipil, gerakan sosial perempuan, Kabupaten Rembang, pabrik semen, ekofeminisme.

\begin{abstract}
This article aim to descript a women social movement who get strategic role for streighten poples opposition movements as agent to struggling democratic of rights, justice and people freedom. As it is the farmer movements, women movement is one of peole's element to struggling their rights. The women movements which discusses in this article is about the Srikandi opposition who lives in Kendeng. Nowadays, in Kendeng has did cement fabric builted by PT Semen Indonesia, a cement producen belonging of government. It will begin operating in 2017. The most Kendeng's people especially the womens decline cement fabric because they are believed it will destruction of water resources and stopped the farms.
\end{abstract}

Keywords: civil society, the women social movements, Rembang region, ecofeminism. 


\section{PENDAHULUAN}

Terra Mater. Bumi adalah perwujudan "Ibu Pertiwi", simbolisasi ini menempatkan kedudukan bumi sebagai kerahiman yang penuh kasih. Ia menjadi pelindung bagi segenap isinya termasuk manusia didalamnya. Bumi dalam pandangan kosmologi timur dipahami berdasarkan prinsip feminin di mana adanya suatu hubungan dialektis dan co-existence yang saling melengkapi satu sama lainnya. Hubungan antara penciptaan dan perusakan, penyatuan dan perpecahan menjadi siklus pergerakan dinamis alam semesta. ${ }^{1}$

Kendeng adalah rahim bumi yang banyak manusia bernaung dibawahnya. Perempuan-perempuan disekitarnya adalah subyek yang menggerakkan aktivitas interaksi dengan alam lewat kerja "domestik" mereka, memasak, mencuci, memandikan anak-anaknya, berternak, mengairi sawah, bercocok tanam, semuanya berkat pasokan air yang tersimpan didalam karst pegunungan Kendeng. Mereka berjalan berkilo-kilo meter, kadang bermil-mil untuk sampai kepada air. Suplai air di Cekungan Air Tanah (CAT) Watu Puth Pegunungan Kendeng Rembang cukup kaya. Bahkan CAT Watu Putih dipakai PDAM Rembang dan Blora untuk mendukung penduduk dua kabupaten

\footnotetext{
${ }^{1}$ Shiva, Vandana. 1988. Staying Alive: Women, Ecology, and Survival in India. London: Zed Books.
}

ini. Kesuburan ini tak tergantikan dengan nominal uang apapun. Warga desa biasa saling membagi sayur, membagi empon-empon (kunyit, jahe, palawija dan lainnya). Mereka hidup guyub rukun tak kurang suatu apa pun.

Maria Mies, seorang feminis, menyebut kegiatan mereka ini sebagai produksi kehidupan, yang mana memiliki hubungan produktif dengan alam, karena mereka tidak hanya mengkonsumsi namun membuat segala sesuatu menjadi tumbuh, hubungan yang tidak ada dominasi. Maka, bukanlah sesuatu yang berlebihan jika sampai hari ini kita masih mendapati kabar perihal anak-anak Ibu pertiwi Rembang yang menjerit-jerit kepada aparat, berpanas-panas dengan capil mereka sembari memandangi truk-truk yang silih berganti mengibaskan debu di muka yang mulai lusuh, beratus kilo meter melakukan perjalanan mereka tempuh demi mendatangi para ahli di altar kampus yang dianggap suci lagi maha tinggi. ${ }^{2}$

Dalam lensa feminisme khas Eropa, perempuan-perempuan ini akan didakwa sebagai yang tertindas karena dianggap melakukan kerjakerja reproduksi alias kerja domestik, namun di dalam ruang sosial mereka, justru mereka adalah subyek yang memiliki peran utama dalam

\footnotetext{
2 Shiva, Vandana dan Maria Mies. 2005. Ecofeminism; Perspektif Gerakan Perempuan Dan Lingkungan. Yogyakarta: IRE Press.
} 
penghidupan atas pekerjaannya. Struktur ekologilah yang menciptakan struktur sosial dan kebudayaan demikian, maka dalam kosmologi mereka, tidak ada unsur penindasan atau patriarki yang terjadi. Patriarki seperti yang dikatakan oleh Walby terkategorisasi menjadi privat dan publik, yang mana privat terjadi dalam rumah tangga dan publik terjadi secara kolektif dimana keduanya saling mempengaruhi, tidak berlaku disini. Begitupun dengan diktum-diktum feminisme gelombang pertama yang terkesan memaskulinasi feminitas. Hal ini seolah membenarkan gejala feminisme yang hosting the oppresor's ideology. Lalu dengan penuh kritik Vandana Shiva mewakili feminis Dunia Ketiga hadir memberi corak feminisme yang lebih kontekstual dengan pengalaman kita, meskipun orang memandang terma feminisme disini terkesan tak lebih dari sekedar metafor.

Hasrat etis dari perempuanperempuan yang mengelola air dapat dijumpai dari bagaimana mereka menampung beban-beban pekerjaan domestik berkaitan dengan air dalam pengasuhan atas anak-anak, atas keluarga, atas ternak, atas tanamantanaman yang menjadi tanggung jawab ekonomi subsisten keluarga. Penduduk Watu Putih menanam padi, dan tidak menjualnya, atau mengganti bilangan beras menjadi bilangan rupiah. Tetapi tradisi ini kemudian lama-lama terkikis dengan hadirnya pelbagai tambang di Pegunungan Kendeng. Mulai dari tambang galian pasir, tambang semen, dan pembalakan pohonpohon Jati untuk kebutuhan industri mebel. Kelangkaan air mulai dirasakan sejak tahun 2000-an. Sejak Soeharto turun di 1998, dan sejak otonomi daerah di tahun 2000, eksploitasi Sumber Daya Alam (SDA) oleh politisi dan pengusaha daerah marak dan tak terkendali lagi. Nurani lokal atas intervensi, dan pengingkaran hak-hak ekologis warga lokal ini mempercepat friksi dan konflik horizontal tak hanya di kalangan warga Pegunungan Kendeng, tetapi menyebar di luar Pegunungan Kendeng.

Kebijakan industrialisasi yang dilakukan sejak zaman Orde Baru secara tidak langsung menimbulkan konsekuensi yang ditanggung oleh rakyat. Konsekuensi dari kebijkan dapat dilihat semakin banyaknya kebutuhan lahan atau tanah (yang umumnya dikuasai rakyat tanpa tanda kepemilikan sesuai kehendak hukum Negara) cukup besar sebagai tempat untuk investasi. Untuk itu Negara perlu memberikan jaminan hukum guna memfasilitasi kebutuhan lahan tersebut, yang pada akhirnya memunculkan konflik pertanahan antara rakyat berhadap-hadapan dengan Negara yang ditopang oleh perangkatnya, yaitu birokrasi dan 
keamanan. ${ }^{3}$ Praktik penjahan ideologi Orde Baru dilawan oleh rakyat dengan gerakan sosial yang pada puncaknya adalah fenomena reformasi.

Sejauh ini, studi-studi tentang persoalan gerakan masyarakat sipil hanya dilakukan oleh Kartodirdjo, Onghokham, Kuntowijoyo dan belakangan ini Siahaan beserta Mustain yang mengkaji mengenahi gerakan masyarakat sipil menemukan variasi baru dalam gerakan sosial dalam konteks negar indonesia. Mereka telah berhasil mengukuhkan pandangan versi Indonesia tentang fenomena historis yang penting tentang gerakan sosial rakyat miskin dan marjinal di pedesaan. Namun, harus diakui, saat ini sangat sedikit para akademisi yang memperhatikan, menganalisis dan melakukan penelitian ilmiah tentang gerakan protes masyarakat sipil secara serius di masa Orde Baru, apalagi masa transisional, reformasi. Sejarah mencatat, berbagai bentuk perlawanan terhadap kekuasaan negara acapkali dilakukan rakyat, baik bersifat secara individual maupun kolektif, terselubung, sekadar aksi unjuk rasa hingga aksi pemberontakan.

Hampir semua aksi perlawanan rakyat yang berkaitan dengan persoalan agraria tidak lepas

${ }^{3}$ Mustain. 2007. Petani VS Negara; Gerakan Sosial Petani Melawan Hegemoni Negara. Yogyakarta: Penerbit Ar-Ruzz Media. Hlm. 72 . dari corak pemerintahan yang tengah berkuasa. Artinya, berbagai bentuk aksi gerakan perlawanan dan bahkan pemberontakan diakibatkan oleh kebijakan negara yang seringkali menjadikan tanah sebagai bagian dari perpolitikan, alat kepentingan penguasa. Meskipun secara normatif pembangunan daerah yang cenderung ke arah industrialisasi menjadi tulang punggung perekonomian, nyatanya ketidakpuasan menyangkut persoalan agraria tetap saja tidak terhindarkan.

Pembangunanmembahasakan segalanya menjadi suatu bentuk universalitas. Sebagai manifestasi dari kapitalisme, pembangunan melihat detail-detail kehidupan melalui teropong kapital. Apa yang dimaksud pembangunan berkiblat pada modernitas negara-negara maju, konon yang telah melewati pengalaman revolusi industri dan revolusi pengetahuan, dianggap gilang-gemilang dalam pencapaian peradaban manusia. Setidak-tidaknya ini dipertahankan secara turuntemurun mengikuti konteks. Mulai dari Comte yang telah membawa teori evolusi menjadi pengetahuan positivistik dengan diawali imajinasi tiga fase perubahan peradaban manusia ke arah yang lebih maju secara direksional dan linier, dilanjutkan fungsionalisme yang phobia terhadap konflik dan mempertahankan status-quo agar social engineering berjalan sesuai cita-cita peradaban, seiring 
dengannya muncul pendikotomian gemeinschaft-gesselschaft, organikmekanik. Dan selanjutnya berkembang menjadi teori modernisasi yang tampil lebih gagah dan maskulin dengan berbagai gaya yang kompleks namun ekstrim dengan menarik tradisionalisme menuju ke modernisme, yakni modernitas yang berkiblat pada masyarakat kapitalisme barat 1950an, masyarakat yang mencapai high mass consumption.

Akibat dari narasi-narasi tersebut apa yang terjadi sesungguhnya penghancuranpenghancuran masif yang mengancam peradaban. Kendeng hanyalah satu dari sekian pemerkosaan bumi oleh proyek maskulinitas dengan dalih 'pembangunan' yang tidak hanya sebatas penghancuran fisik semata, namun ekses dari eksploitasi rahim ini juga menjamah ranah penghancuran ilmu pengetahuan. Yang kemudian menjadi sumber kekerasan bagi alam dan perempuan, juga tak terkecuali seluruh umat manusia.

Perempuan, masyarakat kesukuan dan kaum tani sebagai suyek pengetahuan dianiaya secara sosial melalui pemisahan ahli dan bukan ahli yang mengubah mereka menjadi kaum tidak berpengetahuan bahkan dalam bidang-bidang kehidupan dimana mereka adalah ahli yang sesungguhnya melalui partisipasi sehari-sehari dan dimana tanggungjawab praktek dan tindakan berada pada mereka seperti dalam sistem kehutanan, pangan dan air. Kekerasan bagi alam: alam sebagai objek pengetahuan ketika ilmu modern merusak integritasnya, baik dalam proses persepsi maupun manipulasi. ${ }^{4}$ Tambang, dalam jejak sejarahnya, memiliki persoalan etik atas lingkungan (Lynch, 2002) dan dia memiliki persoalan dengan pembangunan ekonomi (Gralau, 2008). Tambang dengan sengaja menyembunyikan perempuan dari peran-peran profesinya karena eksklusif banyak dilakukan oleh pekerja laki-laki. Tambang bersifat amat maskulin. Bahaya tambangtambang baru adalah mengubah masyarakat agraris menjadi masyarakat tambang. Mau tidak mau, perempuan dan anak-anak akan diseret menjadi penambang informal jika alam sudah hancur dan tak bisa menyediakan persediaan untuk ekonomi keluarga para petanikarena air tercemar, karena air tidak ada, karena situasi lingkungan memburuk karena proses-proses ekstraksi tambang. De-agrikulturasi masyarakat Watu Putih ini akan menghancurkan perikehidupan mereka. Tidak hanya sistem sosial yang rusak, tetapi, paling pertama adalah sistem ekologi di Watu Putih. Sebagai penopang suplai air bagi

4 Shiva, Vandana. 1997. Bebas dari Pembangunan: Perempuan, Ekologi, dan Perjuangan Hidup di India. Yogyakarta: Yayasan Obor Indonesia. 
PDAM Rembang dan Blora, Rembang akan mengalami darurat air jika benar tambang semen ini berdiri, dan menjadi besar, dan menghabisan hutan-hutan di Pegunungan Kendeng. Kurang lebih 300-an ibu-ibu Watu Putih meminta seluruh alat-alat berat keluar dari wilayah tapak tambang dan perlawanan masih dilanjutkan bahkan mendapat dukungan dari kota-kota di Indonesia, misalnya: Jakarta, Semarang, Solo, dan lainlain.

Tulisan ini menemukan bagaimana agensi perempuan tidak hanya tercetak bahwa perempuan adalah sebagai korban, tetapi secara diskursif perempuan secara politis aktif melawan perusakan lingkungan dalam sebuah paradigma tidak eksploitatif-bahwa mereka akan kehilangan air sebagai penopang kebutuhan hidup, atau kehilangan air sebagai potensi kapital perikehidupan mereka. Tetapi perempuan-perempuan ini mengungkapkan bahwa ketahanan lingkungan, air dan ekologi Watu Putih merupakan metafora dari ibu mereka, yang memberikan susunya, dan seluruh kesuburannya, untuk anak-anaknya. Perempuanperempuan Kendeng memandang ekosistem Watu Putih Rembang sebagai ibu, dan mereka adalah anakanak yang harus melindungi ibunya dari serangan penghancuran oleh tambang-tambang.

\section{LANDASAN LITERATUR}

\section{Masyarakat Sipil}

Semenjak awal tahun 1990an, konsep masyarakat sipil (civil society) menjadi wacana di lingkungan akademik maupun aktivis gerakan sosial. Masyarakat madani (civil society) sering disebut masyarakat warga, masyarakat kewargaan, masyarakat sipil, beradab, atau masyarakat berbudaya. Istilah civil society berasal dari bahasa latin, yaitu civitas dei atau kota Illahi. Asal kata civil adalah civilization (beradab). Civil society secara sederhana dapat diartikan sebagai masyarakat beradab.

Istilah masyarakat madani sebenarnya hanya salah satu di antara beberapa istilah lain yang sering kali digunakan orang dalam menerjemahkan civil society ke dalam bahasa Indonesia. Di samping, istilah masyarakat madani juga sering digunakan masyarakat warga atau masyarakat kewargaan, masyarakat sipil, masyarakat beradab atau masyarakat berbudaya.

Bagi kalangan tertentu, konsep masyarakat sipil dipersepsi mengandung makna yang setara dengan masyarakat madani. Namun demikian, bila ditinjau dari sejarah konsepnya, maka kedua istilah ini (masyarakat sipil dan masyarakat madani) jelas berangkat dari konteks yang berbeda. Masyarakat sipil berasal dari konsep potret dan sejarah Barat/Eropa. Sedangkan konsep masyarakat madani merujuk 
pada sejarah Islam di awal penyebarannya.

Di lihat dari bahasa asalnya, civil society berasal dari bahasa latin "civilis societas" yang mengacu kepada gejala budaya perorangan dan masyarakat. Dalam konteks yang lain, kata civil society sebenarnya berasal dari khasanah kosa kata Latin, yaitu civitas dei atau "Kota Illahi" sehingga secara harpiah kata civil society diterjemahkan dengan masyarakat kota. Akar kata civil adalah civilization, yang berarti beradab sehingga civil society sering pula diterjemahkan dengan masyarakat beradab. Oleh karena itu, civil society dapat dimaknai sebagai sebuah masyarakat yang memiliki peradaban (civility) yang dibedakan dari masyarakat yang tidak beradab atau barbarian atau masyarakat jahiliyah.

Dawam Rahardjo (1999) menjelaskan bahwa Cicero (106-43 SM) menyebut masyarakat sipil sebagai sebuah masyarakat politik (political society) yang memiliki kode hukum sebagai dasar pengaturan. Pada sejarah awalnya, masyarakat seperti ini ada di lingkungan perkotaan. Bahkan bisa pula dikatakan bahwa proses pembentukan masyarakat sipil itulah yang sesungguhnya membentuk masyarakat kota. Masyarakat kota telah menjadikan kehidupannya dibawah kendali hukum sipil (civil law).
Pada tahap selanjutnya, konsep civil society dikaitkan dengan fenomena kemunculannya pasar ekonomi modern. Kemudian karakter ini dikembangkan dengan melibatkan aspek-aspek penyempurnaan moral dan budaya, perhatian terhadap pelaksanaan rule of law oleh pemerintahan, satu semangat publik, dan pembagian kerja (division of labor) yang kompleks sebagai bagian dari karakter utama masyarakat sipil. ${ }^{5}$ Adam Ferguson dan beberapa pemikir lainnya di Skotlandia mulai memisahkan antara fenomena masyarakat sipil dan negara. ${ }^{6}$ Masyarakat sipil dinilai merupakan fenomena munculnya kemandirian masyarakat yang berseberangan dengan negara dalam arti kritis terhadap struktur dan kebijakan negara.

Dalam realitas empirisnya masyarakat sipil mengorganisasi dirinya secara independen dari negara sekaligus mempunyai landasan pengetahuan yang menjadikan mereka berbeda dari masyarakat biasa yang tidak kritis dan pasif dalam struktur sosial yang bisa jadi menindas mereka. Secara mendasar masyarakat sipil menempatkan dirinya dalam posisi yang kritis terhadap negara dengan terus melakukan upaya perubahanperubahan dalam bidang-bidang

\footnotetext{
${ }^{5}$ Chandhoke, Neera, 1995, State and Civil Society. Explorations in Political Theory, Sage Publication, New Delhi ${ }^{6}$ Hikam AS, Muhammad. 1996. Demokrasi dan Civil Society. Jakarta: LP3ES. HIm. 2.
} 
sosial, ekonomi dan politik serta kontrol terhadap kekuasaan.

Secara sosiologis, landasan popular tentang civil society dapat merujuk pada pendapat Cohen dan Arato yang menggunakan tiga bagian (three part model) dalam analisisnya tentang ranah sosial bagi peradaban, yaitu negara (masyarakat politik/political society), korporasi (masyarakat ekonomi/economical society), dan komunitas (masyarakat sipil/civil society).

Menurut IFDA civil society berisi sekelompok orang yang memiliki kesadaran kritis tentang peranan yang dimainkannya, bahwa esensi dari sejarah adalah perjuangan rakyat sipil untuk menentukan sendiri jalan hidupnya, sesuatu yang dapat disebut sebagai proses pemanusiaan manusia (humanization of man). Adapun menurut Gramsci civil society adalah golongan yang secara sadar ingin membongkar historical block yang dibangun oleh hegemoni dua sistem pertama yakni negara dan pasar.

Friedman menyatakan bahwa ketakberdayaan masyarakat berpangkal pada perampasan kemampuan secara sistematik (systematic process of disempowerment) oleh negara dan pasar melalui globalisasi kapitalisme di tingkat global dan praktek pembangunan di tingkat negara berkembang. Hal tersebut sependapat dengan pendapat Sen bahwa kemiskinan dan ketakberdayaan adalah efek dari perampasan kemampuan (capability deprivation). Menurut Nurcholish Madjid bahwa pengertian masyarakat madani juga dapat disebut masyarakat berbudaya. Pengertian Madani merujuk pada istilah Madinah, Yaitu sebuah kota di wilayah Arab, tempat masyarakat Islam di bawah pimpinan Muhammad SAW di masa lalu pernah membangun peradaban tinggi. Kata "Madinah" berasal dari bahasa Arab, yaitu "Madaniyah", yang berarti peradaban. Oleh karena itu, pengertian masyarakat madani juga dapat diartikan sebagai masyarakat beradab.

Dalam proses demokrasi, masyarakat diberikan peranan yang luas untuk ikut aktif berpartisipasi dalam negara dan pemerintahan, baik secara langsung maupun tidak langsung (melalui perwakilan). Dengan pemberian kesempatan kepada masyarakat untuk terlibat dalam negara dan pemerintahan merupakan suatu proses pemberdayaan masyarakat dan memfasilitasi masyarakat untuk memperkuat kemampuannya. Hal tersebut adalah salah satu esensi dari pengembangan civil society.

Di lain pihak, masyarakat biasa (parokial) dan masyarakat sipil dapat dijelaskan dengan istilah mass society dan public society sebagaimana dikemukakan Wright Mills (1956). Mass society adalah masyarakat yang cenderung pasif, 
tidak kritis terhadap kekuasaan dan pada sisi berseberangan public society merupakan masyarakat kritis, independen dan mampu mengorganisasi diri untuk melakukan tuntutan terhadap ketidakadilan. Sedangkan masyarakat sipil adalah lembagalembaga yang kritis terhadap Negara (Chandoke, 2005). Selain kritis terhadap negara civil society mempunyai kemandirian dalam banyak hal. Bahwa civil society adalah suatu wilayah yang menjamin berlangsungnya perilaku, tindakan, dan refleksi mandiri, tidak terkungkung kehidupan material, dan tidak terserap dalam jaringanjaringan politik resmi. Di dalamnya tersirat pentingnya suatu ruang publik yang bebas (the free public sphere), tempat dimana transaksi komunikasi yang bebas bisa dilakukan oleh warga masyarakat (Hikam, 1996: 3). Namun demikian, masyarakat sipil berbeda dengan masyarakat politik yang mencakup semua aktor terogarnisasi terutama partai politik dan organisasi kampanye. Masyarakat sipil melingkupi kehidupan sosial berorganisasi yang terbuka, sukarela, lahir secara mandiri, setidaknya berswadaya secara parsial, otonom dari negara, dan terikat pada tatanan legal atau seperangkat nilai-nilai bersama. Selanjutnya Diamond menekankan bahwa masyarakat sipil bersedia aktif secara kolektif dalam ruang publik untuk mengekspresikan kepentingan-kepentingan, hasrat, pilihan, dan ide-ide mereka, untuk bertukar informasi, mencapai sasaran kolektif, mengajukan tuntutan pada negara, memperbaiki fungsi struktur negara, dan untuk menuntut akuntabilitas negara. Masyarakat sipil yang kritis dan mandiri secara esensial didukung oleh orientasi pasarnya, sehingga para aktor di dalamnya mengakui prinsip-prinsip otoritas negara dan rule of law. Agar bisa tumbuh berkembang dan mendapat jaminan rasa aman ia membutuhkan perlindungan dari tatanan hukum yang terlembagakan. Sehingga, masyarakat sipil bukan hanya membatasi kekuasaan negara tetapi juga melegitimasi otoritas negara bila otoritas itu didasarkan pada rule of law (Diamond, 2003). Dalam konteks inilah, Wakil Perdana Menteri Malaysia Dato Anwar Ibrahim saat itu, ketika datang ke Indonesia pada forum Istiqlal tanggal 26 September 1995, melontarkan istilah masyarakat madani sebagai padanan kata civil society, yang dikaitkan dengan konsep "Kota Illahi" atau "Masyarakat Kota" yang telah tersentuh oleh peradaban maju. Makna dasar dari masyarakat madani pada waktu itu, yaitu suatu komunitas yang telah memiliki karakter, dan keteraturan sosial berlandaskan pada nilai-nilai hukum. Untuk mempertegas pandanggannya, kemudian Diamond (2003: 281-283) mengajukan lima ciri masyarakat sipil yang dapat 
dibedakan dari masyarakat politik. Kelima ciri tersebut, yaitu :

a. Masyarakat sipil memusatkan perhatiannya pada tujuan-tujuan publik bukannya tujuan privat.

b. Masyarakat sipil dalam beberapa hal berhubungan dengan Negara tetapi tidak berusaha merebut kekuasaan atas Negara atau mendapat posisi dalam negara; ia tidak berusaha mengendalikan politik secara menyeluruh.

c. Masyarakat sipil mencakup pluralisme dan keberagaman. Artinya, organisasi yang sektarian dan memonopoli ruang fungsional atau politik dalam masyarakat bertentangan dengan semangat pluralistik.

d. Masyarakat sipil tidak berusaha menampilkan seluruh kepentingan pribadi atau komunitas. Namun, kelompokkelompok yang berbeda akan menampilkan atau mencakup kepentingan berbeda pula.

e. Masyarakat sipil haruslah dibedakan dari fenomena Civic community yang lebih jelas meningkatkan demokrasi.

Civic community adalah konsep yang lebih luas dan lebih sempit sekaligus: lebih luas karena ia mencakup semua jenis perhimpunan (termasuk parokial); lebih sempit karena ia hanya mencakup perhimpunan yang terstruktur secara horizontal di seputar ikatan yang sekira mempunyai kebersamaan, kooperatif, dan saling mempercayai.

\section{Gerakan Sosial Masyarakat}

Sejumlah gerakan tertentu memang membawa pergeseran dalam fokus analisis dibidang teori gerakan sosial, akan tetapi aliranaliran pemikiran di antara para elite politik dan di dalam kebudayaan umumnya juga menghasilkan pemahaman bahwa pembaharuan itu sah dan rasional. Aktivisme yang menuntut adanya pelayanan negara terhadap kepentingan masyarakat (welfare state activism) di Eropa dan juga gerakan masyarakat raya (great society), serta program memerangi kemiskinan (war on poverty) yang dicanangkan oleh pemerintahan John F. Kennedy dan Lindon B. Johnson di Amerika Serikat pada awal dekade tahun 1960-an turut menciptakan iklim pembaruan. Menurut Ritzer dan Goodman, program pencanangan peperangan terhadap kemiskinan di Amerika ini, merupakan cara khas strategi masyarakat modern yang 
menyakini bahwa dapat ditemukan dan diterapkan penyelesaian rasional atas masalah kemiskinan itu (Ritrzer dan Goodman, 2003 : 630).

Demikian juga program yang dicanangkan oleh Bad Goderberg dari Partai Sosial Demokrat (SPD) di Jerman Barat pada tahun 1960-an pada gilirannya menandai keinginan kaum sosialis untuk menciptakan konsensi-konsensi ideologis guna melibatkan diri dalam pembangunan institusi-institusi di Jerman Barat. Pada saat agenda-agenda pembaharuan mulai direalisasikan, makin banyak gerakan radikal dan aliran pemikiran yang mempertanyakan struktur-struktur penting yang tengah dibaharui. Pada saat agenda-agenda pembaharuan mulai direalisasikan, makin banyak gerakan radikal dan aliran pemikiran yang mempertanyakan strukturstruktur penting yang tengah dibaharui, seperti aliran Marxis atau tidak, termasuk unsur-unsur gerakan Golongan Kiri Baru (New Left). Aliran pemikiran ini telah menggunakan istilah-istilah seperti "kapitalisme" dan "struktur kekuasaan" (power structure), guna membuat definisi mengenai sumber masalah-masalah sosial. Secara khusus, bahwa Marxisme Barat bangkit kembali dalam skala besar, khususnya di Eropa Barat, di mana Marxisme menjadi ideologi utama para intelektual muda (Anderson, 1976). Selanjutnya, pengaruh ini juga kian terasa di Amerika Serikat, namun agak lebih terbatas. Di samping itu, bahwa aliran pemikiran kalangan sosialis pada waktu itu, juga turut serta mempengaruhi perspektif gerakan sosial. Pemikiranpemikiran sosialis ini kebanyakan disebarkan dalam suatu wadah formal melalui media ilmiah jurnajurnal populer dan lebih menonjol bertahan lama seperti New Left Review (Media Massa Kiri Baru) dan Monthly Review (Jurnal Bulanan).

Kerangka teoritis social movement yang bukan hanya collective action akan menjadi perspektif dalam melihat gerakan anti semen yang merupakan gerakan yang berkembang di Indonesia. Gerakan Sosial Baru menjelasan mengapa gerakan sosial terbentuk yang jawabannya terbatas pada kondisi dalam batasan luas. Penjelasan mengenai teori gerakan sosial baru dikonsepkan dengan elaborasi teoritik antara teori mobilisasi sumber daya dan teori gerakan sosial berorientasi identitas. Teoritisi Mobilisasi Sumberdaya menjelaskan aspek-aspek perjalanan dari kondisi yang ada saat ini untuk mencapai tujuan-tujuan dari gerakan tersebut. Dalam teori mobilisasi sumberdaya aspek diskontinuitas dan kontinuitas merupakan manajemen sumberdaya, dinamika organisasi, proses politik, strategi dan jejaring sosial. Sementara itu ada empat faktor mempengaruhi proses mobilisasi yaitu organisasi, 
kepemimpinan, peluang politik dan sifat alamiah lembaga politik.

Dalam konsep organisasi dan kepemimpinan, keberadaan organisasi formal menentukan kontinuitas dari gerakan dalam mencapai tujuannya, sehingga dinamika organisasi dalam gerakan sosial menentukan bagaimana gerakan sosial bekerja mencapai tujuan-tujuannya dengan memobilisasi sumberdayanya, baik itu sumberdaya material maupun non material. Sumberdaya tersebut dapat berupa sumberdaya manusia, sumberdaya dana, dan jaringan. Keberadaaan jaringan sosial (network social) memberikan koherensi dan hubungan horisontal dalam kelompok, dan juga merupakan fasilitator kunci untuk melakukan aksi kolektif. Telah dapat diargumentasikan bahwa semiinformal network, atau konteks mikro-mobilisasi, menyediakan hubungan antara tingkat mikro dan makro dari pembentukan kelompokkelompok. konsep-konsep dan variabel-variabel yang dipergunakan dalam penelitian ini. Konsep-konsep yang dipergunakan sebagai kerangka untuk penelitian adalah faktor-faktor ideologi yang mempengaruhi kemunculan dari gerakan sosial, faktor diskontinuitas sebagai ciri dari bentuk gerakan sosial yang ekspresif, dan faktor kontinuitas yang mencirikan gerakan-gerakan yang bertujuan untuk mencapai tujuantujuannya. Dengan demikian, dalam menganalisis proses dan dinamika terjadinya gerakan sosial, menurut perspektif kedua teori tersebut, harus dilihat dalam 8 (delapan) aspek determinannya, yakni: Organisasi gerakan sosial; Pemimpin dan kepemimpinan; Sumberdaya dan mobilisasi sumberdaya; Jaringan dan partisipasi; Peluang dan kapasitas masyarakat dalam melakukan gerakan sosial; Identitas kolektif; Solidaritas; dan Komitmen.

Gerakan sosial tak hanya berbicara konsep mobilisasi sumber daya. Akan tetapi, juga mempertimbangkan aspek identitas gerakan. Kondisi tersebut dikarenakan mobilisasi sumberdaya gagal menjelaskan beberapa ekspresi kuat Gerakan sosial feminisme, environmentalism, perdamaian, perlucutan senjata, dan gerakan perekonomian lokal. Ini bukan proaktif atau offensive. Dengan tepat Cohen (dalam Singh, 2010:170) menyatakan bahwa aktor-aktor kolektif kontemporer dengan sadar berjuang melawan kekuasaan untuk secara sosial membangun identitas baru, untuk menciptakan ruang demokratis bagi aksi sosial otonom. Apa yang penting adalah: (1) menemukan serangkaian kondisi, faktor dan kekuatan pendorong yang digunakan para aktor-aktor kolektif untuk menciptakan identitas, solidaritas dan mmpertahankan itu semua; (2) memeriksa hubungan antara musuhmusuh dengan isu-isu dalam konflik; dan (3) untuk 
mengenali latar sosial dan budaya aksi kolektif sebagaimana kondisi dan kekuatan pendorong ini membentuk dan mencetak perenungan dan kesadaran para aktor dalam situasi konkrit aksi kolektif dan gerakan sosial. Kasus gerakan sosial masyarakat Pegunungan Kendeng utara merupakan ombinasi dari mobilisasi sumberdaya beserta degan pengembangan aspek identitas. Aspek tersebut didasrakan atas pertimbangan berapa karasteristik gerakan. Dalam kasus ini strategi gerakan yang dilakukan mengunakan pemikiran mobilisasi sumber daya yang jelas. Mulai bagaimana mengembangkan isu serta memobilisasi sumberdaya yang ada. Akan tetapi, gerakan sosial yang menyangkut perlawanan pembangunan pabrik semen memiliki tujuan untuk melestarikan alam. Gerakan ini dapat juga dideskripsikan sebagai gerakan environmentalism. Asumsi tersebut didasarkan atas tujuan akhir dari gerakan ini adalah menolak eksploitasi pegunungan karst.

\section{Gerakan Sosial Masyarakat Perempuan Terhadap} Lingkungan: Ekofeminisme Menurut Vandana Shiva dan Maria Mies, Ekofeminisme ialah istilah baru untuk gagasan lama yang tumbuh dari berbagai gerakan sosialgerakan perempuan, perdamaian, dan ekologi-akhir tahun 1970-an dan awal 1980-an. Istilah Ekofeminisme pertama kali digunakan oleh Francoise D' Eaubonne, baru populer ketika maraknya protes dan aktivitas penentangan perusakan lingkungan hidup yang memicu bencana ekologis yang terjadi berulang-ulang. Terminologi ini dihadirkan kembali oleh Shiva dan Mies dalam buku "Ekofeminisme:

Gerakan

Perempuan dan Lingkungan" sebagai kritik mereka terhadap proses globalisasi saat ini, yang mengatasnamakan modernisasi untuk kesejahteraan umum, akan tetapi dalam praktiknya adalah bentuk penindasan yang berbasiskan penguasaan manusia dan sumber daya alam demi akumulasi modal.

Shiva dan Mies bersepakat bahwa dalam beberapa tahun terakhir isu-isu yang berkaitan dengan kelangsungan hidup dan pemeliharaan kehidupan, tidak hanya persoalan perempuan, anak-anak, dan umat manusia pada umumnya, tetapi juga berkait dengan makin hancur dan langkanya flora dan fauna di bumi serta kian membutuhkan perhatian khusus. Shiva dan Mies menganalisis bahwa penyebab kehancuran yang menjadi ancaman kehidupan di muka bumi ini ialah sistem yang disebut "kapitalis patriarkal" dunia. Dalam perspektif kapitalis patriarkal ini, perbedaan diartikan sebagai hirarki dan keseragaman sebagai syarat kesetaraan.

Tentu dalam struktur macam ini terdapat ketidakadilan, karena 
memungkinkan negara-negara Utara mendominasi negara-negara Selatan; laki-laki mendominasi perempuan, dan makin banyak penjarahan terhadap sumber daya alam. Sehingga, terjadi ketimpangan dalam distribusi keuntungan ekonomi penguasaan alam. Modernisasi "pembangunan" dan "perkembangannya" merupakan faktor yang paling bertanggungjawab terhadap degradasi alam saat ini, pun yang membuat dominasi laki-laki terhadap perempuan bertambah kuat.

Dari pengalaman dan wawasan kedua penulis buku tersebut, sistem di Dunia Ketiga sekarang dibangun dan dijalankan lewat penindasan atas perempuan dan penjajahan terhadap orang-orang "asing" dan tanah air mereka dan bagi alam, sehingga menimbulkan kerusakan. Dalam perspektif feminis, kerusakan dan kemunduran ekologi akan berdampak besar terhadap perempuan dan anak. Persoalan umum yang muncul akibat dampak negatif politik global yang tak terlihat itu dialami oleh perempuan dalam kehidupan sehari-hari mereka. Krisis pangan dan air bersih adalah dampak nyata yang kini dihadapi oleh perempuan dan anak-anak di berbagai belahan dunia. Krisis pangan berdampak besar terhadap tingginya angka malnutrisi pada anak serta angka kematian ibu dan anak. Kekurangan gizi pada anak-anak dan perempuan akan berlanjut sampai dewasa dan hingga generasi mendatang. Krisis air bersih memberikan kontribusi sebesar 34,6 persen bagi angka kematian anakanak di Dunia Ketiga. Setiap tahun, 5 juta anak meninggal karena penyakit diare.

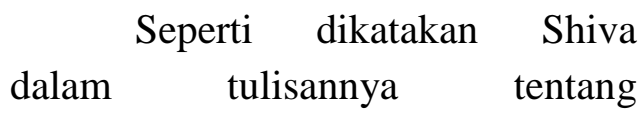
"Pemiskinan terhadap Lingkungan: Perempuan dan Anak-anak yang Jadi Korban", bahwa ekonomi global memiliki banyak sekali kebijakan yang menjamin kesejahteraan perempuan dan anak, tetapi dalam kenyataannya merekalah yang pertama kali diperosokkan dalam jurang kemiskinan. Sumber daya alam yang sejatinya dipakai sebagai sumber untuk mempertahankan hidup kini makin ter-erosi oleh tingginya permintaan atas sumber tersebut oleh ekonomi pasar yang didominasi kekuatan global. Perempuan menjadi kelompok yang mengalami ketertindasan yang lebih besar daripada laki-laki, sekaligus menjadi kelompok terdepan dalam melakukan protes atas kerusakan lingkungan. Tiap aspek kerusakan lingkungan diterjemahkan sebagai ancaman yang berbahaya bagi kehidupan generasi mendatang.

Di sisi lain, Shiva dan Mies mencatat bahwa telah banyak strategi survival dan perlawanan lokal yang dikembangkan perempuan terhadap kerusakan dan keterpurukan ekologi akibat sistem "patriarkal-kapital". Misalnya, kini lebih dari sepertiga rumah tangga di Afrika, Amerika 
Latin, dan negara-negara maju dikepalai oleh seorang perempuan (di Norwegia jumlahnya mencapai 38 persen dan di Asia 14 persen). Kemudian di Jerman muncul gerakan perlawanan dan penolakan terhadap rencana penggunaan tenaga atom; perempuan Chipko di Himalaya telah melakukan perlawanan terhadap perusakan lingkungan akibat penebangan kayu; gerakan aktivis Sabuk Hijau di Kenya; dan perjuangan perempuan Jepang menentang polusi makanan akibat stimulasi kimia, jaringan pertanian komersial, dan produsen-konsumen untuk memenuhi kebutuhan diri sendiri; gerakan perempuan miskin di Ekuador untuk menyelamatkan hutan sebagai sumber makanan bagi ikan dan udang; perjuangan beriburibu perempuan di negara-negara Selatan untuk menuntut manajemen dan distribusi air yang lebih baik, konservasi tanah, penggunaan tana, dan perawatan sumber kehidupan mereka (misalnya: hutan, bahan bakar, dan makanan ternak/hewan) melawan kepentingan industri. Perlawanan-perlawanan ini memperlihatkan bahwa perempuanperempuan di seluruh dunia merasakan kemarahan dan ketidakpuasan serta bertanggungjawab untuk memelihara dan melindungi sumber alam yang ada serta menghentikan perusakan lingkungan.

\section{PEMBAHASAN}

Pergerakan perempuan dalam aksi tolak tambang pabrik semen di Rembang berperan sangat penting karena mereka selalu menjadi garda paling depan dalam setiap aksi. Perempuan-perempuan yang terdiri dari warga desa sekitar rencana lokasi tambang pabrik semen di Rembang ini mayoritas adalah sebagai petani. Mereka adalah ibuibu rumah tangga yang dalam kesehariannya bekerja membantu suami bekerja di sawah dan ladang.

Rencana penambangan dan pendirian pabrik semen di Rembang membuat warga khawatir akan risiko dan dampak buruk yang mengancam sumber mata air mereka. Terutama para petani perempuan, mereka akan kesulitan untuk memenuhi kebutuhan air untuk mengairi sawah, ternak dan kebutuhan sehari-hari seperti mandi, mencuci dan memasak. Karena mereka sebagai perempuan juga ikut bertanggungjawab terhadap kebutuhan sehari-hari.

Rencana lokasi tambang berada pada gunung Watuputih yang terletak di desa Tegaldowo, Timbrangan, Pasucen dan Kajar. Dalam penelitian Dinas ESDM Provinsi Jawa Tengah pada tahun 1998 disebutkan bahwa perbukitan Gunung Watuputih merupakan bentang alam karst dengan fenomena khas berupa lapies, gua kering dan berair dan lembah kering. Formasi ini terdiri dari batu gamping dolomitan, dengan organisme 
pembentuknya terutama ganggang, koral, dan foraminifera, yang terbentuk pada lingkungan laut dangkal pada zaman Pliosen.

\section{Pergerakan}

Masyarakat Rembang dari berbagai desa baik itu di sekitar rencana lokasi tambang dan pabrik atau yang jauh dari rencana lokasi bergabung dalam satu jaringan yang menamakan dirinya Jaringan Masyarakat Peduli Pegunungan Kendeng di Rembang (JM-PPK Rembang). Berdirinya kelompok ini tidak terlepas dari peranan perempuan karena ketua koordinator utamanya adalah juga seorang perempuan. Dalam jaringan ini ada kelompok-kelompok yang disebut paguyuban di masing-masing desa, tiap desa memiliki nama paguyubannya sendiri.

Perempuan yang terdiri mulai dari remaja sampai ibu-ibu mengadakan pertemuan rutin untuk membahas agenda pergerakan dan penguatan kapasitas. Dalam setiap pertemuan mereka mendatangkan tokoh perempuan yang bersedia berbagi ilmu pengetahuan kepada mereka guna penguatan kapasitas dalam pergerakan. Mulai dari berbagai keterampilan mengolah hasil bumi menjadi penganan yang menarik sampai pada belajar mengenai dampak dan risiko bencana yang akan timbul apabila gunung watuputih ditambang. Setiap kegiatan mereka adakan secara sukarela dan swadaya, para pembicara juga hadir secara sukarela. Mereka sadar betul akan bahaya tambang semen yang mengancam kelestarian lingkungan hidup dan masa depan anak cucu mereka.

\section{Tambang Ancaman Bagi Perempuan}

Tidak jauh dari rencana lokasi tambang semen di kecamatan Gunem ada beberapa penambangan yang sudah beroperasi lama. Kawasan penambangan berada pada desa Tahunan kecamatan Sale Kabupaten Rembang. Ada beberapa perusahaan tambang yang beroperasi dan menjadi contoh nyata penyumbang kerusakan baik itu kerusakan alam, kesehatan maupun moral. Kerusakan alam berupa matinya beberapa sumber mata air dan menurunnya debit mata air yang berada tidak jauh dari lokasi penambangan. Debu dari polusi truk pengangkut batu beterbangan dan menutupi daun-daun pada tanaman yang berakibat pada rusaknya tanaman petani dikarenakan tanaman yang tertutup debu tidak bisa berfotosintesis dengan sempurna. Selain itu debu juga membuat sesak nafas.

Ancaman yang mengerikan adalah tentang virus HIV/AIDS. Paling tinggi angka penderita HIV/AIDS adalah di kecamatan Sale yang merupakan kawasan pertambangan. Di Sale sering terjadi protes warga karena mulai 
menjamurnya kafe-kafe dan warung remang-remang. Disitulah diduga awal mula penyebaran virus HIV/AIDS. Hal ini tidak jauh beda seperti kasus di Sekotong Lombok Nusa Tenggara Barat. Ketua Komisi Penanggulangan AIDS Provinsi Nusa Tenggara Barat Soeharmanto mengatakan tambang rakyat berpotensi menjadi daerah penyebaran HIV dan AIDS. Pasalnya kawasan itu diduga juga menjadi lahan bagi wanita pekerja seks.

Kasus HIV/AIDS di wilayah Kabupaten Rembang dari tahun 2004-2013 mencapai angka 149 kasus. Grafiknya cenderung naik dari tahun ke tahun. Dan yang mengerikan, dari 149 penderita, 80 diantaranya dinyatakan meninggal dunia. Dari data Dinas Kesehatan Kabupaten Rembang, penderita HIV/AIDS tersebar di seluruh Kecamatan. Mulai dari Kecamatan Sale yang memiliki jumlah penderita paling banyak dengan 21 kasus, Kragan 19 kasus, Lasem 17 kasus, Rembang 16 kasus, Pamotan 12 kasus, dan Sumber 11 kasus. Untuk Kecamatan Sluke, Pancur, dan Kaliori masing-masing sembilan kasus. Sulang dan Gunem samasama 7 kasus. Kecamatan Sarang 6, Sedan 5, dan Bulu hanya satu kasus. Khusus tahun 2013 sampai dengan bulan September diketahui ada 29 kasus, 13 penderita di antaranya berasal dari kalangan Ibu Rumah Tangga. Sangat menyedihkan jika melihat banyak perempuan menjadi korban akibat kultur sosial yang berubah akibat keberadaan perusahaan tambang.

\section{Pelanggaran Hukum dan Dampak Bagi Perekonomian Warga}

Rencana Pendirian dan penambangan pabrik semen di Rembang terus berjalan, PT. Semen Indonesia masih terus menjalankan prosesnya, begitu juga dengan PT.SIR, dan PT. GMM serta menyusul Bosowa, meskipun sudah ada penolakan keras dari warga sekitar dan aktivis lingkungan. Pabrik Semen ini siap beroperasi pada 2017 untuk memenuhi kebutuhan semen di Jawa Tengah dan Jawa Barat yang sebelumnya disuplai dari Tuban. Menurut PT Semen Indonesia, proses pembangunannya saat ini sudah mencapai 95 persen.

Izin Usaha Lokasi Penambangan yang sudah dikantongi oleh Semen Indonesia masuk dalam kawasan Cekungan Air Tanah Watuputih yang merupakan kawasan lindung geologi, hal tersebut sangat jelas tertuang dalam Perda No 14 tentang Rencana Tata Ruang Wilayah Rembang tahun 2011 pasal 19. Serta tertuang dalam Perda No 6 Tahun 2010 tentang Rencana Tata Ruang Wilayah Provinsi Jawa Tengah pasal 63 yang menyatakan bahwa Cekungan Air Tanah Watuputih Merupakan Kawasan Lindung imbuhan air. Letak titik 
koordinat Cekungan Air Tanah Watuputih telah disebutkan dalam Keppres RI No 26 tahun 2011.

Pemerintah mengatakan bahwa rencana penambangan dan pendirian pabrik semen ini akan meningkatkan perekonomian daerah melalui peningkatan $\mathrm{PAD}$, namun semua itu belum tentu benar, mari kita berhitung seberapa besar kerugian yang akan diderita jika kerusakan alam akibat penambangan pabrik semen terjadi. Dalam Neraca Wilayah dan Analisis Statistik Badan Pusat Statistik (BPS) Rembang menyebutkan bahwa berdasarkan catatan pertumbuhan ekonomi tahun 2011 di Rembang adalah 4,4\%. Sumbangan sektor pertanian adalah $44,75 \%$, sektor perdagangan $17,38 \%$ dan paling kecil adalah sektor pertambangan sebesar $1,67 \%$.

Sumbangan sektor pertanian masih menempati nilai tertinggi, hampir mencapai 50\%, ini berarti sumbangsih dari sektor pertanian sangat mempengaruhi perekonomian di Rembang. Bayangkan saja jika sektor pertanian mati, lantas apa yang akan terjadi pada kabupaten ini? Separuh dari Pendapatan Asli Daerah (PAD) akan hilang. Akan tetapi sebaliknya jika sektor pertambangan dihapuskan maka PAD hanya berkurang $1,67 \%$, angka tersebut bisa ditutupi dari usaha ekonomi kerakyatan. Jika pemerintah mau memberdayakan warga eks karyawan tambang dalam kegiatan ekonomi kerakyatan sesuai dengan kemampuan dan sumber yang ada, maka angka $1,67 \%$ tersebut mudah saja dikejar, daripada harus mempertaruhkan sektor pertanian yang menyumbang 44,75\%. Dari potensi yang ada, pemerintah harus jeli memperhatikan segala keperluan untuk memajukan usaha pertanian. Penambangan hanya akan menimbulkan perusakan alam, apalagi jika dilakukan dikawasan lindung. Umur ekonomis perusahaan tambang sangat terbatas, berbeda dengan umur ekonomis lahan produktif pertanian yang tidak terbatas.

\section{Pelestarian Kawasan Karst}

Bukti-bukti lapangan semakin menguatkan bahwa Kawasan karst Gunung Watuputih harus dilindungi terkait temuantemuan ratusan mata air, gua dan sungai bawah tanah yang masih mengalir dan mempunyai debit bagus. Proses produksi semen akan berpotensi merusak sumber daya air yang berperan sangat penting bagi kehidupan warga sekitar dan juga warga Rembang dan Lasem yang menggunakan jasa PDAM (PDAM mengambil mata air yang bersumber dari gunung Watuputih). Dalam data temuan JM-PPK Rembang ada 49 gua dan 109 mata air yang berada dekat pada rencana lokasi penambangan. Pelestarian kawasan karst Watuputih sebagai tulang punggung kebutuhan air masyarakat 
Rembang merupakan hal penting yang perlu diperjuangkan.

\section{KESIMPULAN}

Gerakan sosial perempuan yang dihadirkan sejak awalnya merupakan suatu usaha untuk mengangkat posisi perempuan. Ini berangkat dari asumsi bahwa peran perempuan dalam kehidupan masyarakat atau ranah kebijakan publik di berbagai belahan dunia dari waktu ke waktu terus berkembang, khususnya di Indonesia. Perkembangan ini tentunya mengarah kepada terciptanya ruang yang memberikan kesetaraan bagi perempuan baik secara individual maupun perempuan sebagai komponen masyarakat. Ayu Ratih, seorang aktivis buruh perempuan, mendefenisikan gerakan perempuan sebagai usaha untuk menerobos batasan yang memisahkan persoalan ketertindasan perempuan dan ketertindasan manusia secara keseluruhan. Ini berarti gerakan perempuan harus menyusun strategi tentang bagaimana memberi warna perempuan pada setiap gerakan pembebasan yang bertujuan untuk menghapuskan segala bentuk diskriminasi dan ketidaksetaraan dalam tata hubungan antar manusia yang beradab.

Dalam kasus Pabrik Semen Rembang, para perempuan telah mewujudkan responnya dalam bentuk gerakan sosial melawan tambang pabrik semen, mereka merasa memiliki hak sebagai masyarakat sipil untuk mengemukakan pendapatnya sebagai input suatu kebijakan sosial.

\section{DAFTAR PUSTAKA}

Candraningrum, Dewi. 2014. Politik Rahim Perempuan Kendeng Menolak Tambang: Kajian Perubahan Iklim dan Seksualitas. www.jurnalperempuan.org.

Diamond, Larry. 2003. Developing Democracy. Yogyakarta: IRE Press.

Fakih, Mansour. 2013 Analisis Gender dan Transformasi Sosial. Yogyakarta: Pustaka Pelajar.

Fakih, Mansour. Runtuhnya Teori Pembangunan. 2013. Yogyakarta: Insist Press.

Foucault, Michel. The History of Sexuality. Vol. 1, An Introduction. Translated by Robert Hurley. New York: Vintage Books, 1980.

Lukiarti, Ming Ming. 2014. Perempuan Rembang Tolak Tambang Semen. www.jurnalperempuan.org.

Manan, Munafrizal. 2005. Gerakan Rakyat Melawan Elit. Yogyakarta: Resist Book.

Mirsel, Robert. 2004. Teori Pergerakan Sosial; Kilasan Sejarah dan Catatan Bibliografis. Yogyakarta: Resist Book. 
Shiva, Vandana dan Maria Mies. 2005. Ecofeminism; Perspektif Gerakan Perempuan Dan Lingkungan. Yogyakarta: IRE Press.

Shiva, Vandana. 1997. Bebas dari Pembangunan: Perempuan, Ekologi, dan Perjuangan Hidup di India. Yogyakarta: Yayasan Obor Indonesia.

Singh, Rajendra. 2001. Social Movement, Old and New: A Post-Modernist Critique diterjemahkan menjadi Gerakan Sosial Baru (GSB). Yogyakarta: Resist Book (terj, Indonesia diterbitkan tahun 2010).

\section{Sumber Internet:}

http://www.bbc.com/indonesia/berita indonesia/2016/04/160413_in donesia_protes_semen_istana. Diakses pada tanggal 1 November 2016. 